\title{
Developing Android-Based Interactive Mobile Learning Software to Improve Students' Analysis and Synthesis Abilities on Basic Electronics
}

\author{
https://doi.org/10.3991/ijim.v14i20.14879 \\ Toto Ruhimat $(\bowtie)$ \\ Universitas Pendidikan Indonesia, Bandung, Indonesia \\ toto.ruhimateupi.edu \\ Tata Risdian Rosdiana \\ Institut Pendidikan Indonesia, Garut, Indonesia
}

\begin{abstract}
This research aims to improve students' analysis and synthesis abilities on electronic component learning material. This research was used the Research and Development (R\&D) method. Data were obtained from tenthgrade students of the Industrial Electronic Engineering Department in Bandung Regency and to see the improvement in learning outcomes in class X.A and class X.B, the analysis uses simple linear regression. The results showed that during the stages of limited and product operational testing, the developed product tends to improve students' analysis and synthesis abilities in basic electronic learning material with electronic component submaterials. Therefore, Android-Based Interactive Mobile Learning has succeeded in creating new and effective ways for students to learn.
\end{abstract}

Keywords - Interactive mobile learning, android, analysis, synthesis, electronic component

\section{$1 \quad$ Introduction}

One of the problems encountered at Vocational High School (SMK) is the lack of media that develops students learning abilities. This research aims to improve students' analysis and synthesis abilities on electronic component subjects in class X at SMK Guna Dharma Nusantara. Class $X$ is a class of Computer Network Engineering study programs, consisting of classes X.A and X.B and both classes have low basic electronics analysis and synthesis competence. The observation results from classes X.A and X.B, showed that students lacked an understanding of the learning material in recognizing basic electronic components. They are only able to identify the material at a glance without proper understanding. Therefore, the formulation of this research is to develop students in learning basic electronic materials with basic competencies in recognizing its components. 
In the presentation and delivery stages, it is necessary to innovate the learning technology with Android-based media to improve students' analysis and synthesis abilities. The problems encountered in this field are as follows:

a) The unavailability of learning models to help students in mastering basic electronic component materials

b) Lack of understanding

c) The underdevelopment of students' analysis and synthesis abilities

These three questions are based on previous research findings of using gamification [1].

The following problems were formulated following the background of the study:

a) How Design, Development, and Testing of Android Based Interactive Mobile Learning for Basic Electronics Material with Subjects of Analyses and synthesis for vocational students?

b) What is the percentage of carrying capacity of Android-Based Interactive Mobile Learning for the mastery of Electronic Component Introductory Materials by vocational students?

c) What are the effects of android-based interactive mobile learning applications on the students' analysis and synthesis abilities?

The objectives of this research include:

a) Knowing the Model of Design, Development, and Testing of Android-Based Interactive Cellular Learning for Basic Electronics Materials with Analysis and Synthesis Subjects for SMK students

b) Knowing the percentage level of the carrying capacity of Android-based Interactive Cellular Learning for the mastery of Electronic Components Introduction Material by SMK students

c) Knowing the effect of interactive mobile learning applications based on android on improving students' analytical and synthesis skills.

\section{Theoretical Review}

\subsection{Mobile learning based on android application}

The term Mobile Learning (M-Learning) refers to the use of information technology (IT) devices, such as PDA, cell phones, laptops, and tablet PCs, in teaching. A learner can utilize mobile devices, irrespective of their location. However, M-Learning is unable to replace electronic or face-to-face learning in class. MLearning as an alternative learning service carried remotely, as described by [2] as Mobile Smart Digital.

The development is based on the following reasons, namely:

a) It is used anytime, irrespective of the users' location 
b) Broad scope

c) Utilizes commercial cellular networks such as GSM, GPRS, and CDMA

d) Availability of the networks everywhere

e) Integration with existing e-learning systems

f) Integration with Academic Information Systems

g) Integration with other systems such as social media

One of the researches that are relevant to this is from[3], about Tablets and apps for promoting robotics, mathematics, STEM education, and literacy in early childhood education.

Android is a Linux-based operating system that is primarily designed for touch screens mobile devices such as smartphones and tablet computers, [4]. It was originally developed by Android, Inc., with financial support from Google, which later purchased it in 2005. The operating system was officially released in 2007, in conjunction with the establishment of the Open Handset Alliance, a consortium of hardware, software, and telecommunications companies, namely, Google, HTC, Motorola, Qualcomm, T-Mobile, and Nvidia, will support the learning environment, as described by[5]. The first Android phone was sold in October 2008, to advance the open standards of cellular devices.

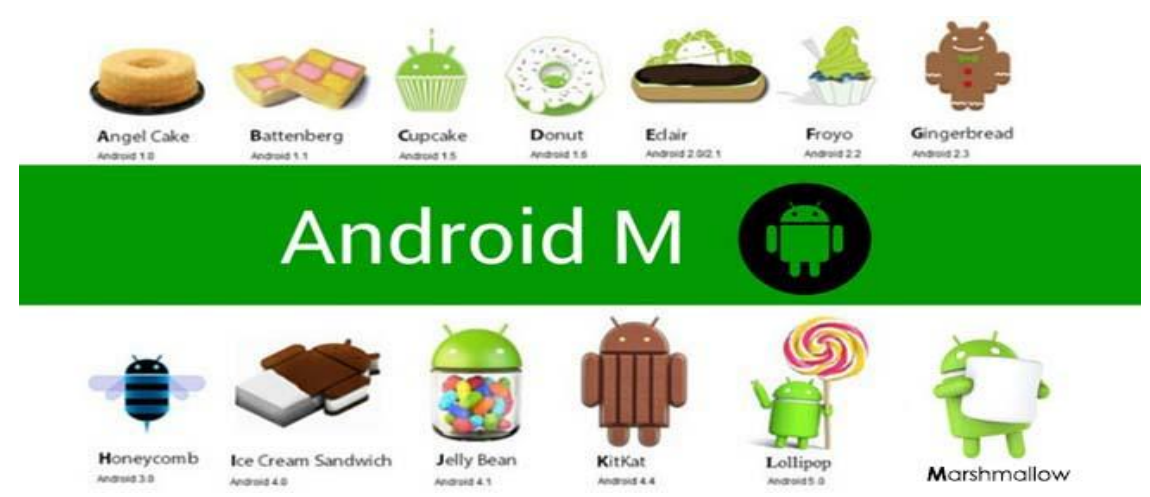

Fig. 1. History of the Android Version

(Source: http://www.infocreativemedia.com/mengenal-android-marshmallow/)

Developers are faced with several choices in manufacturing Android-based applications, as recommended by[5]. However, they need to use Eclipse as an IDE to design their applications due to its direct support from Google. According to [6], Android is an open-source software stack that includes an operating system, middleware, key applications, and a set of Application Programming Interface (API) to design a mobile application using the Java programming language. Android-based applications are freely developed, easily downloaded, and utilized according to the users' specifications.

Adobe Flash is a computer software used to create vector and animated images. Files generated from this software are in the .swf format and played on web browsers 
equipped with Adobe Flash Player. One of its advantages is the few programming codes used to manage the animation. Furthermore, it communicates with other programs such as HTML, PHP, and Databases using an XML approach. Subsequently, this tends to be collaborated with the web, due to the advantages such as its ability to output small size files. The latest version of Macromedia is Macromedia Flash 8, which is modified by Adobe Systems developers to Adobe Flash CS3.

\subsection{Basic electronics analysis and synthesis ability}

The introduction of Basic Electronics subjects at the vocational school level requires a lot of students' analytical and synthesis abilities. This demand is following the opinion of [7], which stated that the improvement of students' learning abilities needs to be evaluated occasionally. This was also reported by [8] while studying the Learning Analysis used to improve formative assessment strategies. This is part of the students' cognitive abilities, therefore the discoveries in this research show many demonstrations and simulations displayed on mobile learning material such as phones. This supports the results from the research by [9], which stated that cognitive study is principally focused on demonstrating the involvement of mental simulations in cognition.

Following mobile learning, which shows simulations and demonstration of materials on basic electronic components, the cognitive abilities of students' analysis and synthesis abilities, tend to be improved. However, assuming the learning of basic electronics is still difficult, it, therefore, needs to be practiced occasionally [10], commended the use of this effort in some domains that lack studies that systematically investigate cognitive adaptations during the acquisition of expertise.

\section{Research Method}

The Research and Development method was employed in this study[11], this is a process used to develop and validate educational products. The development cycle is organized into several steps as follows: Research and information collection, planning, developing the preliminary form of the product, field testing, main product revision, main field testing, product revision operations, operational field testing, final product revision, dissemination and distribution as shown in Figure 2.

In the series of model tests, researchers used Modeling analysis in class XA and X.B. After obtaining an Android Based Interactive Mobile Learning model test for the equally high results in class X.A and X.B, then the model is used in Basic Electronic learning so that it will get a different percentage of achievement between class X.A and class X.B. In the last stage, the findings of the Android Based Interactive Mobile Learning model are used in learning to see the improvement in learning outcomes of analysis and synthesis. To analyze the improvement in learning outcomes in class X.A and class X.B, the analysis uses simple linear regression statistics[13], with the following formula. 


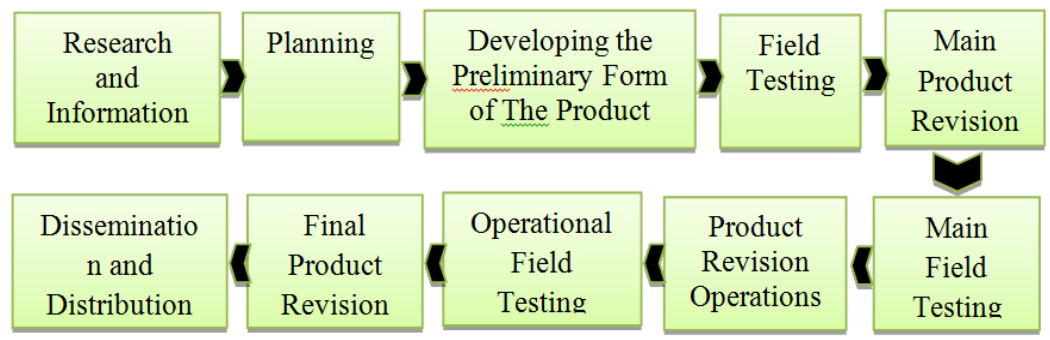

Fig. 2. Steps involved in the Research and Development (R\&D) Method [12]

$$
\hat{Y}=a+b x
$$

This simple linear regression calculation process is carried out using SPSS version 23. The comparison between the influence of the variables $X=$ Android Based Interactive Mobile Learning and $\mathrm{Y}=$ Analytical and synthesis learning outcome is done after the findings model is formulated.

\section{$4 \quad$ Results and Discussion}

4.1 Design, development and testing of android based interactive mobile learning for basic electronics material with subjects of analyses and synthesis.

Several steps are involved in the development of Android-based Interactive Mobile Learning, such as the initial learning products following basic electronic subjects taught in class X.A and X.B at vocational school. Furthermore, it also involves developing learning designs with basic competencies to recognize electronic components. Here are the three main stages in the creation of Android-based Interactive Mobile Learning: The First Steps:

a) Design of Android Based Interactive Mobile Learning, there are: Creating visual of Display Loading and Main Menu

b) Making Product Design Display of Material and Instructors

c) Creating Display of Evaluation

The Second Steps: Development of Android Based Interactive Mobile Learning for Basic Electronics Material Through Adobe Flash CS 5.5. Third Steps: Testing of Android Based Interactive Mobile Learning for Basic Electronics Material.

The all of visualization for developed Android-Based Interactive Mobile Learning model chart consists of designed sketches and visual illustrations displayed on the android mobile phone, as shown in Figures 3,4, 5 and 6. 
Paper-Developing Android-Based Interactive Mobile Learning Software to Improve Students’ Analysis...
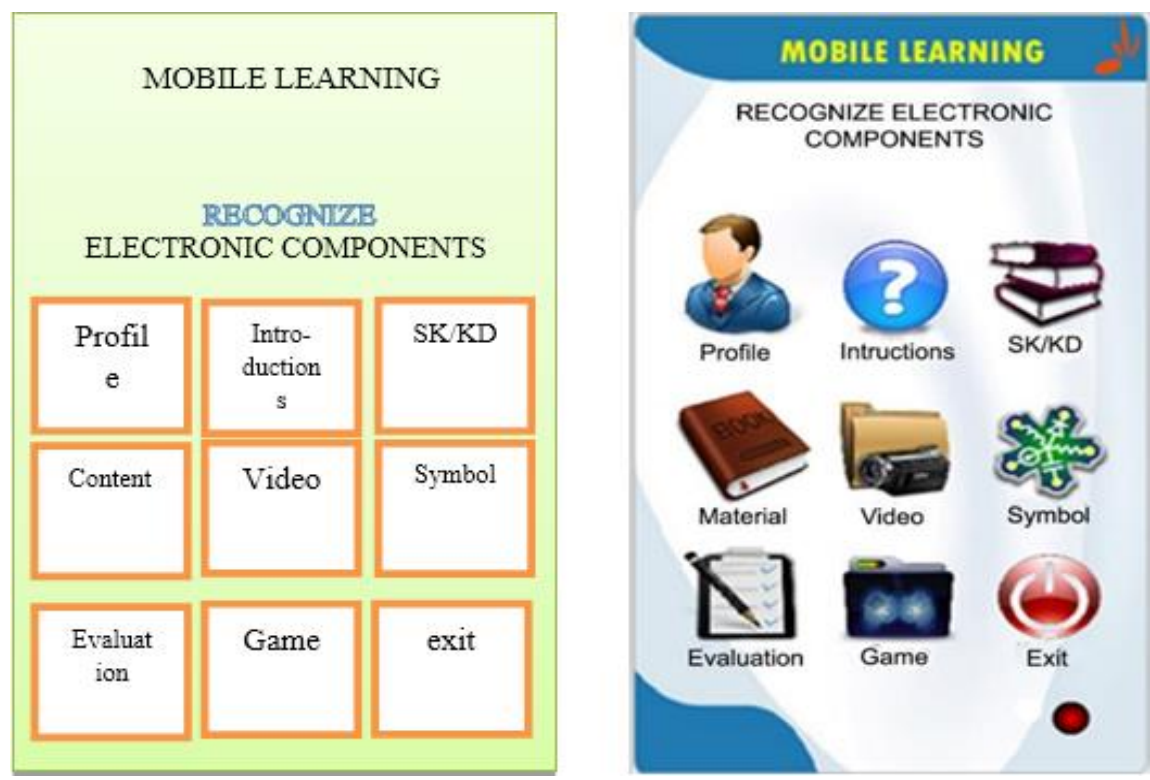

Fig. 3. The Display of Loading and Main Menu on Android Based Interactive Mobile Learning
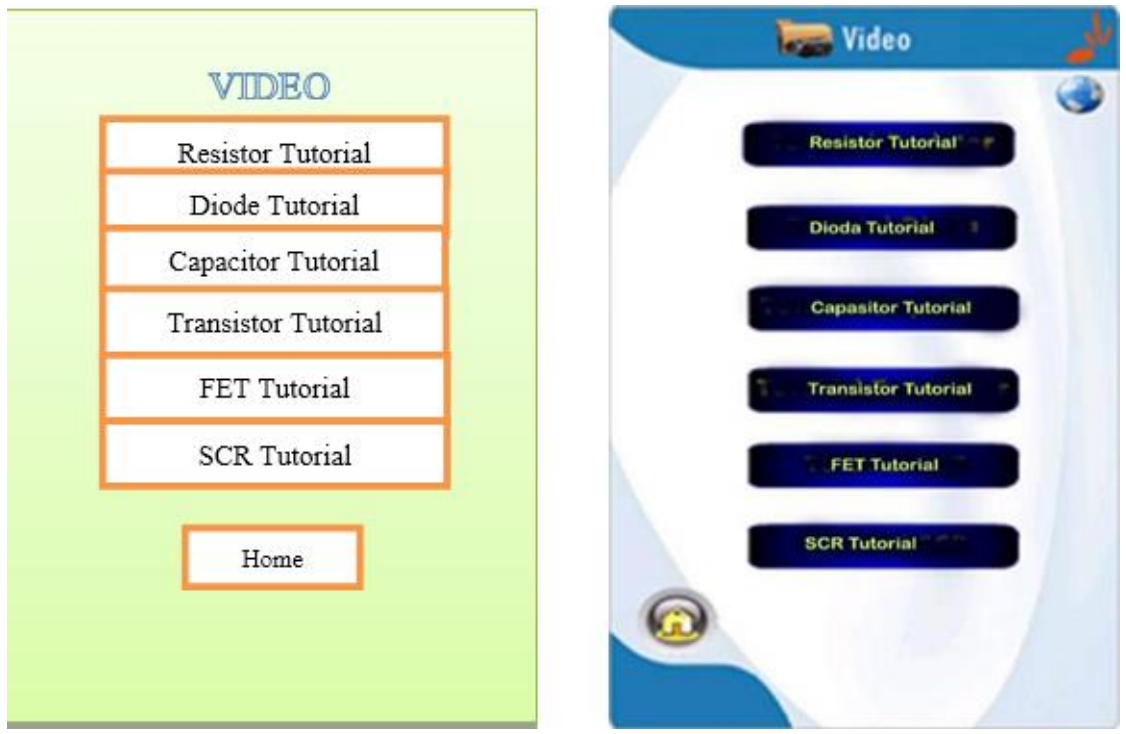

Fig. 4. The Display of Material and Instructors on Android Based Interactive Mobile Learning 

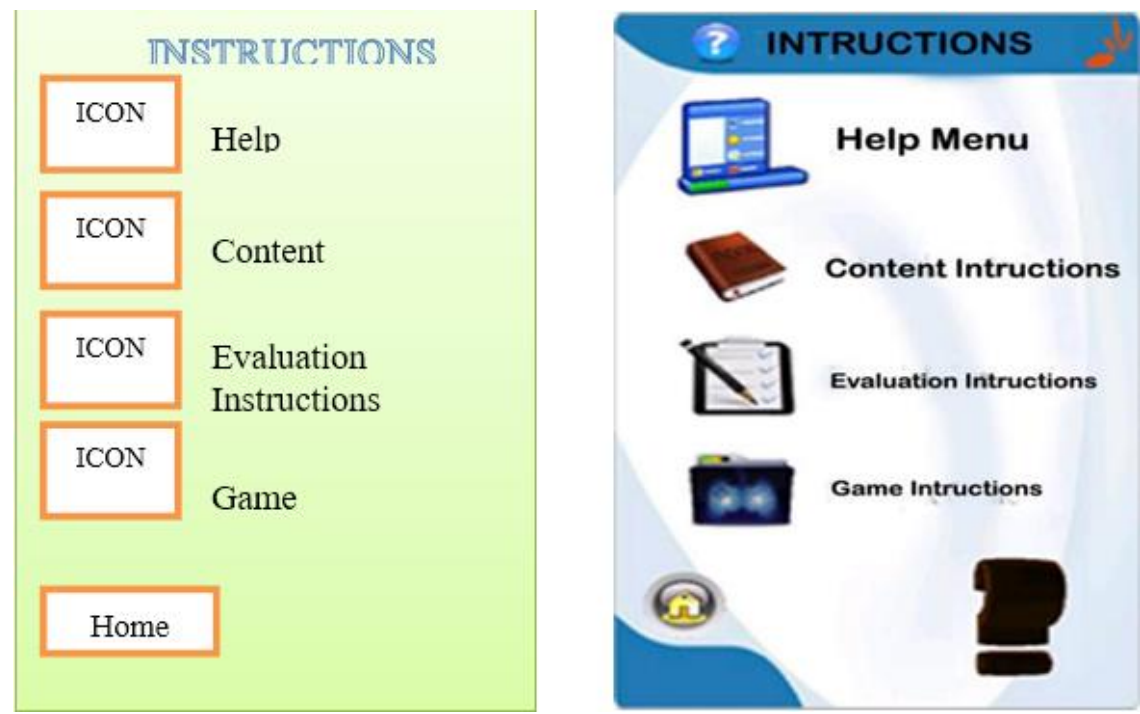

Fig. 5. The Display of Evaluation on Android Based Interactive Mobile Learning
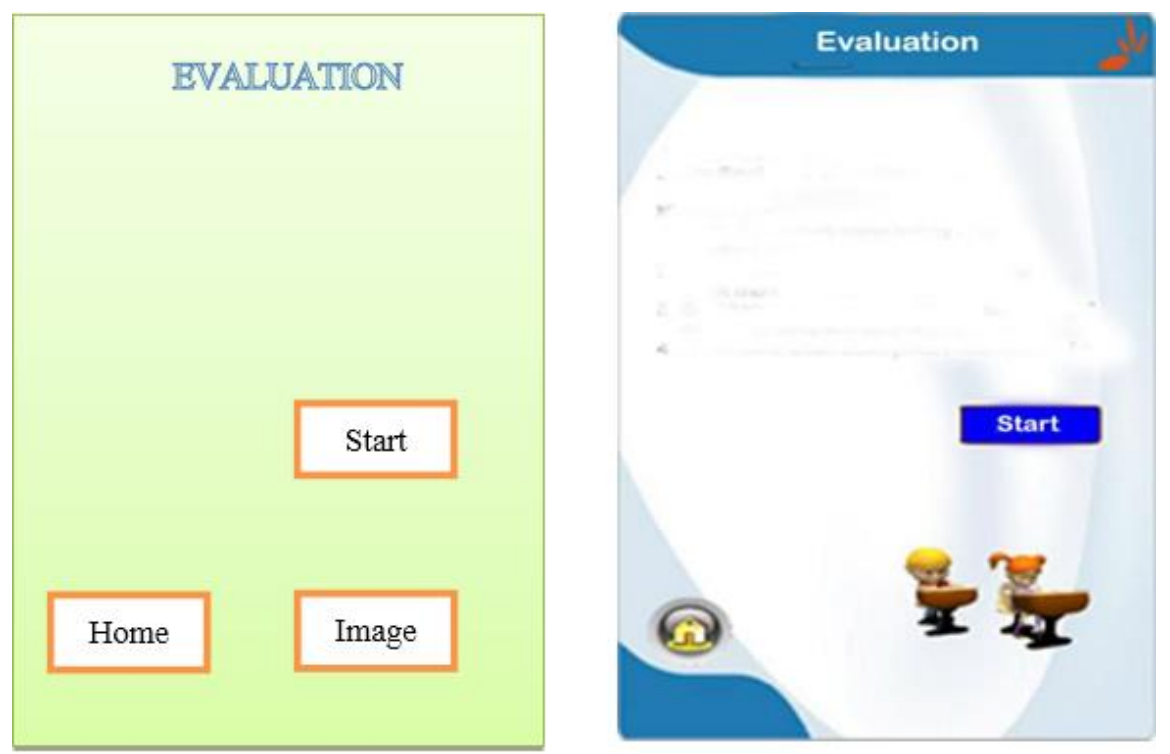

Fig. 6. The Display of Evaluation on Android Based Interactive Mobile Learning

Design development starts with developing a flowchart view graph, which serves as a reference by using the Adobe Flash CS5.5 program. The Action script 3 command programming language was used to create an Android-based Interactive Mobile Learning application and used to link the scene to the command. The display of Adobe Flash CS5.5 program is shown in figures 7 and 8. 

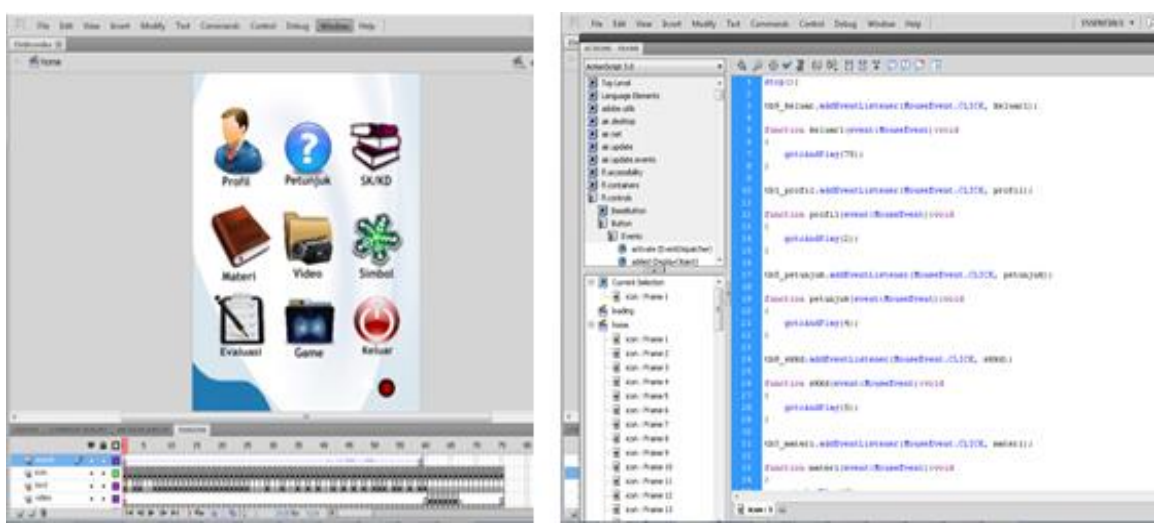

Fig. 7. The Display of Adobe Flash CS 5.5 Application with Home Menu of Interactive Mobile Learning Based on Android
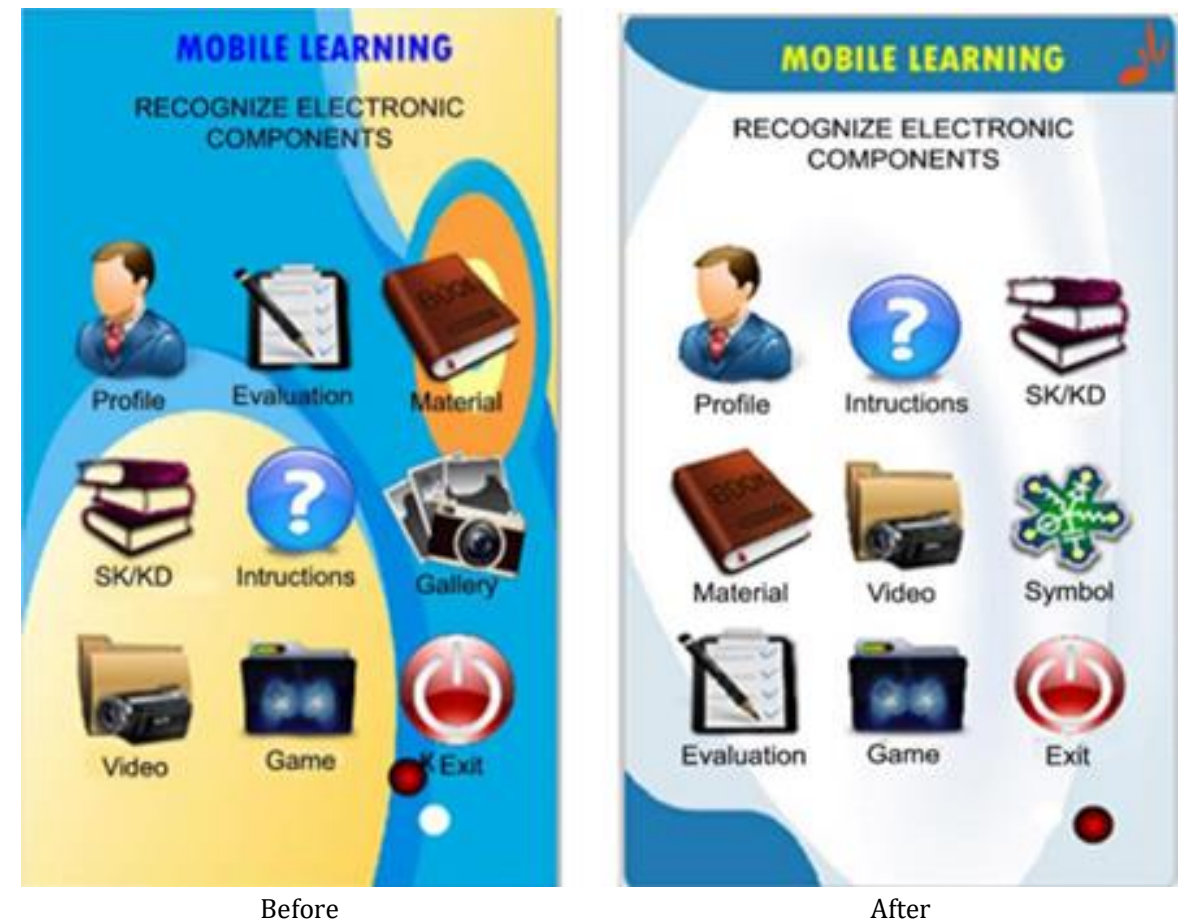

Fig. 8. Display of Interactive Mobile Learning Based on Android Revised Results using Adobe Flash CS 5.5 with ActionScript 3

To test the research findings model, each product stage is used in the basic electronics learning process to measure students' analysis and synthesis. Every 3 times the revised trials during the development of the model are carried out in the class with the experimental method. From the three experiments, the average post-test results 
were obtained both from class X. A and class X.B. So, to see the effect of using this finding model, a statistical analysis of Model Summary is used, the results obtained can be seen as in the figure 9 below.
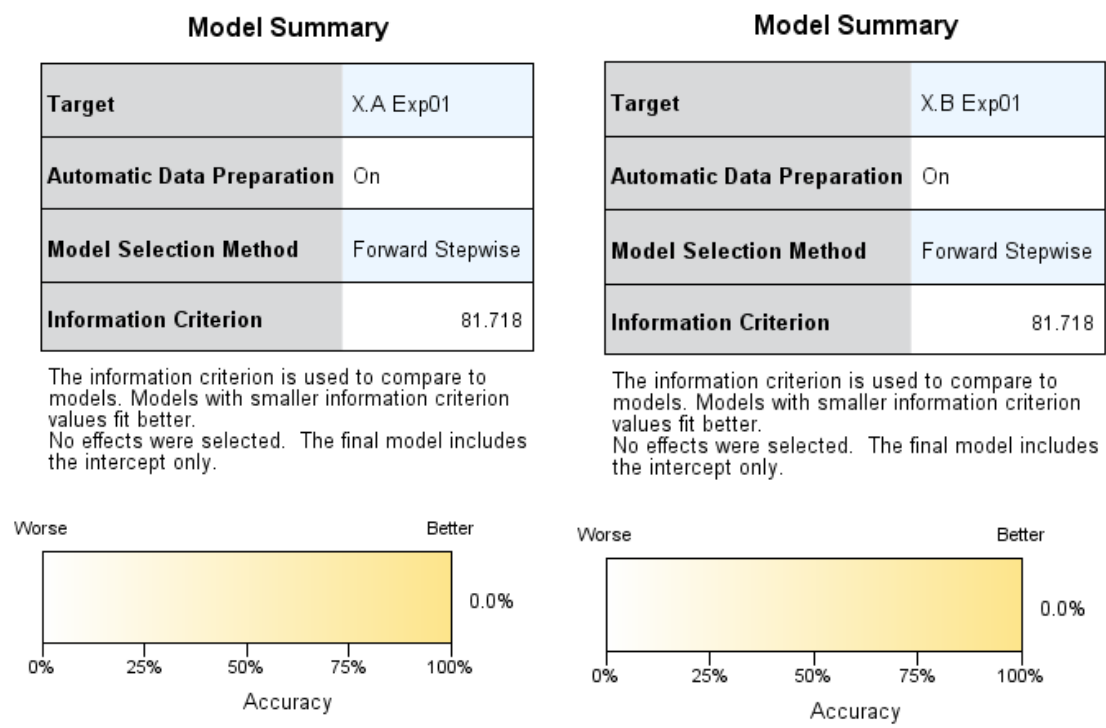

Fig. 9. Result Modeling Testing of Android Based Interactive Mobile Learning for Basic Electronics Material on Class X.A and Class X.B

\subsection{Percentage of carrying capacity of android-based interactive mobile learning for the mastery of electronic component introductory materials by vocational students}

In the learning process using Android-Based Interactive Mobile Learning, students are expected to have individual and group responsibilities. This is under the research products conducted by [14] on the mobile interactive aspects. The role of media in learning activities has eased the teacher's task in delivering academic content. A currently used educational media is the computer-based learning application. According to [15], this education technology consists of software and hardware. The role of educational media is considered capable of assisting teachers in improving the quality of learning. For example, the implementation of an Android-based interactive learning model is the development of mobile education tends to be carried out anywhere and at any time. This is in accordance with [16] which stated the reasons M-Learning is referred to the use of mobile information technology (IT) devices, such as PDAs, cell phones, laptops, and tablet PCs, in teaching. Therefore, it is part of electronic and distance learning.

The developed Android-based interactive mobile learning was intended to be able to optimize students[17], stated that the mobile learning technique is increasingly 
popular and acts as a good instructional medium. There are several media provided by the school, namely:

a) Print media in the form of textbooks, modules, worksheets

b) Visual images, photos, PowerPoint slides

c) Audio and video visual, PowerPoint slides with speakers

The results from observations and surveys showed that the majority of the students in grade $\mathrm{X}$ in the department of Industrial Electronics possess android smartphones. Additionally, expert review of learning material reported that it is appropriate to increase student motivation to learn. This discovery is supported by researches conducted by [18], on the effect of mobile learning in increasing students' Analysis and synthesis outcomes. Furthermore, this is also following [19], which stated that instructional material content, either written, mediated, or facilitated by an instructor, also includes information that serves as a learning objective and a guide for learners to achieve success.

According to [20], the content of teaching materials, which is facilitated by the instructor to achieve certain goals, is either in written or printed form. However, several assessments on these materials have been conducted by experts, namely:

a) The suitability of the material with learning objectives

b) The suitability of material images

c) The suitability with material specifications

d) The systematic material presentation

e) Readability of the material

f) The accuracy of the test exercise with key answers

g) Accuracy of grammar used in the delivery of the material

h) Accuracy in using basic spelling, punctuation, and electronic symbols during the presentation

i) Clarity of instructions given for the ease of material exploration

j) Completeness of the help menu presented in the learning media

Based on the assessment by experts concerning the feasibility of the material, the results from the data before the revision showed a quality of 55\%. Meanwhile, $75 \%$ feasibility was required, therefore, the material contents were provided for expert validation. After the first revision, the results were re-checked from the revised material, and $87.5 \%$ was obtained, therefore, the contents of the material were feasible. Furthermore, the results from the teacher provided input scopes with a first percentage of 65 . However, it was revised following the standards or the competency of the basic curriculum and a percentage of 85 . Therefore, the teaching material using android-based interactive mobile learning media is feasible for students [21]. This research is based on the studies conducted by[22], which stated that mobile application needs to be interactive, attractive and easy to use for most of the targeted population because the majority of the people do not intend spending time learning the application. 
Furthermore, the results from the review conducted by media experts showed that three stages participate in the development process, namely initial product, main and operational field revisions. This is in accordance with the study carried out by [23] which stated that the media can conduct the following:

a) Capture, store and display an object or event

b) Re-display the object or event in various ways-based requirements

c) Display an object or event meaningfully.

The quality of data during the initial revision or improvement of the product obtained was $43 \%$, which is not feasible for learning. Subsequently, the researchers conducted another revision, and $65 \%$ was obtained, however, the results were not yet suitable for use and were revised. The results from the various stages of the research obtained a percentage of 91.6, which is feasible and smart criteria. Therefore, this model needs to be used as a learning material. As reported by[24] on Smart Digital for Mobile Communication for the learning process.

\subsection{The effects of android-based interactive mobile learning applications on the students' analysis and synthesis abilities}

The effect of the Android Based Interactive Mobile Learning Application model was determined through a testing process by using the statistical regression analysis. This model was used because the experimental process as part of the development research was carried out twice in classes X.A and X.B. The analysis and synthesis abilities of the students in this research tend to increase due to the use of androidbased interactive mobile learning [25]. It was stated in the data that an average score of 52 was obtained before using android-based interactive mobile learning. However, these results did not attain the standard with an improvement in the students' abilities and an average score of 87.17 obtained after the implementation. This discovery is supported by [26] which stated that the use of android learning can provide effective academic achievement.

The students' abilities of analysis and synthesis serve to differentiate parts, identify elements, reintegrate, and perceive a system from different points of view. During this research, it was discovered that students can focus their thinking in series, which consist of numerous components, how they function, their influence on the circuit, and the consequences assuming they do not need functional effectively. The students tend to focus on the problem and then try to discover conical and precise solutions. These findings support the studies conducted by [27], on the cognitive and academic benefits of a meta cognitive-analysis.

Furthermore, electronic components involve sure students' ideas, such as identifying the value and characteristics of these components, comparing it with one another. Other discoveries showed students the ability to analyze several basic electronic components as a part of the whole circuit. This supports the results of the study conducted by [28], which stated that cognitive flexibility and working memory are correlated. 
Based on the findings from this research, the analytical and synthesis ability of vocational students are included in the category of cognitive flexibility in learning completeness, as formulated by [29] in their research on the effectiveness of cognitive-behavior therapy and flexibility in a perfectionist. Following the data, it was previously stated that almost $99 \%$ of students had not yet completed their learning, however, the highest score was only 75. Furthermore, after the implementation of android-based interactive mobile learning, the highest score obtained was 80, while the students' analytical and synthesis abilities increased by $36 \%$ with an average value of 80 .

This discovery showed that students experience a strengthening of their cognitive ability due to the functional structure, which was obtained while learning with android-based interactive mobile learning. This is in accordance with [30] research on cognitive structure. It is also observed in how students link (synthesize) any problem encountered with the desired ideal condition. The cognitive level synthesized was reported in the research conducted by [31], which stated that the strengthening of this ability tends to be the intervention that is currently practiced. Students combine theories that emphasize the functioning of a series of electronic components with functional theories concerning their respective work system. This discovery is easy to implement using the learning model from the study conducted by[32], which stated that relatively simple general taxonomy aids practitioners, consumers, and professionals to precisely evaluate and improve models, methodologies and results.

The final results from this study showed that students can predict which components are interconnected, or vice versa. This discovery is stated in the research conducted by[33] concerning cognitive development on the aspects of analysis and synthesis, which are marked by a significant increase with an average gain of 35 and a percentage of 26.7. Following these results, android-based interactive mobile learning can improve students' cognitive abilities in the aspects of analysis and synthesis of basic electronic components learning materials. This discovery is following [33], regarding cognitive software engineering, a research framework, and roadmap.

After a regression test of experiment-01 and experiment-02 in class X.A. showed an increase in the ability of analysis and synthesis when learning to use android-based interactive mobile learning applications. The test results are as follows:

Table 1. A N O V A

\begin{tabular}{|c|l|c|c|c|c|c|}
\hline \multicolumn{2}{|c|}{ Model } & Sum of Squares & df & Mean Square & F & Sig. \\
\hline \multirow{3}{*}{1} & Regression & 6.54 & 1 & 6.54 & 0.579 & $.454^{\text {b }}$ \\
\cline { 2 - 7 } & Residual & 259.7 & 23 & 11.291 & & \\
\cline { 2 - 7 } & Total & 266.24 & 24 & & & \\
\hline
\end{tabular}

a. Dependent Variable: X.An Exp02-Analysis-Synthesis b. Predictors: (Constant), X.An Exp01-Analysis-Synthesis 
Table 2. Coefficients

\begin{tabular}{|c|l|c|c|c|c|c|}
\hline \multirow{2}{*}{ Model } & \multicolumn{2}{|c|}{ Unstandardized Coefficients } & $\begin{array}{c}\text { Standardized } \\
\text { Coefficients }\end{array}$ & \multirow{2}{*}{ t } & \multirow{2}{*}{ Sig. } \\
\cline { 3 - 5 } \multicolumn{2}{|c|}{} & $\boldsymbol{B}$ & Std. Error & Beta & & \\
\hline \multirow{2}{*}{1} & (Constant) & 76.444 & 9.27 & & 8.247 & 0 \\
\cline { 2 - 7 } & X.An Exp01-Analysis-Synthesis & 0.104 & 0.137 & 0.157 & 0.761 & 0.454 \\
\hline
\end{tabular}

a. Dependent Variable: X.An Exp02-Analysis-Synthesis

Whereas in class X.B results in increased analysis-synthesis ability as shown in the following table. From the results of the SPSS output a simple linear equation can be formulated as follows. $\hat{Y}=76.44+0.104 x$

After a regression test of experiment-01 and experiment-02 in class, X.B showed an increase in the ability of analysis and synthesis when learning to use android-based interactive mobile learning applications. The test results are as follows:

Table 3. A N O V A

\begin{tabular}{|c|l|c|c|c|c|c|}
\hline \multicolumn{2}{|c|}{ Model } & Sum of Squares & df & Mean Square & F & Sig. \\
\hline \multirow{3}{*}{1} & Regression & 47.178 & 1 & 47.178 & 8.01 & $.009^{\mathrm{b}}$ \\
\cline { 2 - 8 } & Residual & 135.462 & 23 & 5.89 & & \\
\cline { 2 - 8 } & Total & 182.64 & 24 & & & \\
\hline
\end{tabular}

a. Dependent Variable: X.B Exp02-Analysis-Synthesis

b. Predictors: (Constant), X.B Exp01-Analysis-Synthesis

Table 4. Coefficients

\begin{tabular}{|c|l|c|c|c|c|c|}
\hline \multirow{2}{*}{\multicolumn{2}{|c|}{ Model }} & \multicolumn{2}{|c|}{$\begin{array}{c}\text { Unstandardized } \\
\text { Coefficients }\end{array}$} & $\begin{array}{c}\text { Standardized } \\
\text { Coefficients }\end{array}$ & \multirow{2}{*}{ t } & \multirow{2}{*}{ Sig. } \\
\cline { 3 - 5 } \multicolumn{2}{c|}{} & B & Std. Error & Beta & & \\
\hline \multirow{2}{*}{1} & Constant) & 60.982 & 6.695 & & 9.109 & 0 \\
\cline { 2 - 7 } & X.B Exp01-Analysis-Synthesis & 0.28 & 0.099 & 0.508 & 2.83 & 0.009 \\
\hline
\end{tabular}

a. Dependent Variable: X.B Exp02-Analysis-Synthesis

From the results of the SPSS output, a simple linear equation can be formulated as follows $\hat{Y}=60.982+0.280 x$. The regression line equation can be used to predict the increasing Analysis and Synthesis ability of vocational high school students in basic electronics subjects, influenced by the use of Android-Based Interactive Mobile Learning Applications.

\section{Conclusion}

In conclusion, Android-Based Interactive Mobile Learning has succeeded in creating the following new and effective strategies for students to learn. Design, Development, and Testing of Android Based Interactive Mobile Learning for Basic Electronics Materials with Subjects of Analysis and Synthesis have been tested using 
a statistics model summary that shows the similarity of the quality of the models both tested in class X. A and X.B.

Android-based Interactive Mobile Learning was developed in the form of mobile smartphones using Adobe Flash CS 5.5 application through the stages of limited and operational testing, which is proven to increase students' understanding. The findings of limited and operational testing in class X. A and X.B showed a significant improvement from the initial and final tests both analytical and synthesis ability. The study also showed a significant increase in the learning outcome percentages in classes X.A and X.B.

Furthermore, the results of the effect test using linear regression statistics showed that the use of Android-based Interactive Mobile Learning in the form of mobile smartphones predicts students' analytical and synthesis ability on basic electronic components. Therefore, the findings of this new product succeeded in creating new and effective ways for students to learn. This conclusion is following the research findings from [1], that students through their involvement seem to have understood the basic concepts of programming and technology as they engaged in practical work in an interdisciplinary authentic environment.

The study is limited to the application of basic electronic subject matter; therefore, the application of different subjects is needed for broader analysis.

\section{Acknowledgement}

This work was conducted in the Laboratory of Educational Technology Department and is partially funded by the University Center of Universitas Pendidikan Indonesia Publication-Research Initiative of Vice-Rector in August 2019.

\section{$7 \quad$ References}

[1] V. Papadakis, S., \& Orfanakis, "The combined use of Lego Mindstorms NXT and App Inventor for teaching novice programmers," Int. Conf. EduRobotics, pp. 193-204, 2016. https://doi.org/10.1007/978-3-319-55553-9_15

[2] D. Darmawan, E. Suryadi, and D. Wahyudin, "Smart Digital for Mobile Communication Through TVUPI Streaming for Higher Education,” Int. J. Interact. Mob. Technol., vol. 13, no. 05, p. 30, 2019, https://doi.org/10.3991/ijim.v13i05.10286.

[3] Stamatios Papadakis and Michail Kalogiannakis, "A Research Synthesis of the Real Value of Self-Proclaimed Mobile Educational Applications for Young Children," Mob. Learn. Appl. Early Child. Educ., p. 19, 2020, https://doi.org/10.4018/978-1-7998-1486-3.ch001.

[4] M. Dorouka, P., Papadakis, S., \& Kalogiannakis, "Tablets and apps for promoting robotics, mathematics, STEM education and literacy in early childhood education,” Int. J. Mob. Learn. Organ., vol. 14, no. 2, pp. 255-274, 2020. https://doi.org/10.1504/ijmlo.2020. 10026334

[5] N. Papadakis, S., Kalogiannakis, M., Orfanakis, V., \& Zaranis, "The appropriateness of scratch and app inventor as educational environments for teaching introductory programming in primary and secondary education," Int. J. Web-Based Learn. Teach. 
Technol., vol. 12, no. 4, pp. 58-77, 2017. https://doi.org/10.4018/978-1-5225-7507-8.ch03 $\underline{9}$

[6] Meier, "Professional Android Application Development.," Indianap. Wiley Pub- lishing, 2009.

[7] W. Pardjono, "Improving the Capability of Analysis, Synthesis, and Evaluation Through Problem Solving Learning," Yogyakarta Univ. Negeri Yogyakarta, 2009.

[8] S. Barana, A., Conte, A., Fissore, C., Marchisio, M., \& Rabellino, "Learning Analytics to improve Formative Assessment strategies.," J. E-Learning Knowl. Soc., vol. 15, no. 3, pp. 75-88., 2019, doi: https://doi.org/10.20368/1971-8829/1135057.

[9] V. \& Winfield, "An architecture for ethical robots inspired by the simulation theory of cognition.,” J. Cogn. Syst. Res., vol. 48, pp. 56-66., 2017, [Online]. Available: https://doi.org/10.1016/j.cogsys.2017.04.002.

[10] J. Boshuizen, Gruber, H., Strasserd, "Knowledge restructuring through case processing: The key to generalise expertise development theory across domains?," Int. J. Educ. Res. Rev., vol. 29, p. 100310, 2020, [Online]. Available: https://doi.org/10.1016/j.edurev. 202 $\underline{0.100310 .}$.

[11] M. Borg, R.W., Gall, "Educational Research an Introduction. 5ed," Longman, Newyork, 2019.

[12] Sugiyono., "Business Research Methods (Quantitative, Qualitative, and Approach R\&D) 4ed.," Bandung Alf., 2018.

[13] G. V. Montgomery, Douglas C., Elizabeth A. Peck., "Introduction to Linear Regression Analysis," New York Wiley, 2012.

[14] Pramudita H.R., "Designing Mobile Learning Applications at Newtonsix Educenter Tutoring Institutions Based on Android," Yogyakarta: Stmik Amikom, 2013.

[15] D. Darmawan, "Information and Communication Technology Education," Bandung. PT Remaja Rosdakarya, 2012.

[16] D. Darmawan, "Mobile Learning in Increasing Interest and Learning Communication Students.," Int. J. Enginering Assoc., vol. 4, no. 1, 2013.

[17] J. V. Kattayat, Sandhya., Josey, Smitha., Asha, "Mobile Learning Apps in Instruction And Students Achievement,” Int. J. Interact. Mob. Technol., vol. 11, no. 1, pp. 143-147, 2017. https://doi.org/10.3991/ijim.v11i1.6420

[18] N. Erlinawati, "Mobile Learning Media for Improving Motivation and Practicum Ability of Stikes Karsa Husada Garut Students," J. Ilmu Pendidik., vol. 14, no. 2, 2016, [Online]. Available: https://doi.org/10.17509/pedagogi. https://doi.org/10.17509/pedagogia.v14i2.38 $\underline{79}$

[19] S. Papadakis, "Evaluating a game-development approach to teach introductory programming concepts in secondary education.," Int. J. Technol. Enhanc. Learn., vol. 12, no. 2, pp. 127-145., 2020. https://doi.org/10.1504/ijtel.2020.106282

[20] D. \& Carey, “The Systematic Design of Instruction, 5ed.,” New Jersey Pearson., 2017.

[21] V. Papadakis, S., \& Orfanakis, "Comparing notice programing environments for use in secondary education: App Inventor for Android vs. Alice.," Int. J. Technol. Enhanc. Learn., pp. 44-72, 2018. https://doi.org/10.1504/ijtel.2018.10008587

[22] A. I. Chohan, Afaq Hyder., Mohd Affandi, Haryanti Awad, Jihad, Che-Ani, "A Methodology to Develop a Mobile Application Model to Appraise Housing Design Quality.,” Int. J. Interact. Mob. Technol., vol. 11, no. 6, p. 4, 2017. https://doi.org/10.3991/ ijim.v11i6.6379

[23] D. M. Gerlach, \& Ely, "Learning Design," Online Ed. Educ. Technol., 2016, [Online]. Available: https://educationaltechnology.net/gerlach-ely-design-model/ . 
[24] D. Darmawan, E. Suryadi, and D. Wahyudin, "Smart Digital for Mobile Communication Through TVUPI Streaming for Higher Education,” Int. J. Interact. Mob. Technol., 2016. https://doi.org/10.3991/ijim.v13i05.10286

[25] S. J. Papadakis, "Is Pair Programming More Effective than Solo Programming for Secondary Education Novice Programmers? A Case Study," Int. J. Web-Based Learn. Teach. Technol., vol. 13, no. January-March, pp. 1-16, 2018, https://doi.org/10.4018/ijwltt .2018010101

[26] F. Aksayli, N. D., Sala, G., \& Gobet, "The cognitive and academic benefits of Cogmed: A meta-analysis,” Educ. Res. Rev., vol. 29, pp. 229-243, 2019. https://doi.org/10.31234/osf.i o/ygrh3

[27] E. R. Miller, M. R., Rittle-Johnson, B., Loehr, A. M., \& Fyfe, "The Influence of Relational Knowledge and Executive Function on Preschoolers' Repeating Pattern Knowledge.," J. Cogn. Dev., vol. 17, pp. 85-104., 2015, https://doi.org/10.1080/15248372. 2015.1023307.

[28] R. M. Nazarzadeh, R. S., Fazeli, M., Aval, M. M., \& Shourche, "Effectiveness of Cognitive- Behavior Therapy on Cognitive Flexibility in Perfectionist.," Psychology, no. 6, pp. 6, 1780-1785., 2015, https://doi.org/10.4236/psych.2015.614174.

[29] Y. Bar-Tal, "When the Need for Cognitive Structure does not Cause Heuristic Thinking: The Moderating Effect of the Perceived Ability to Achieve Cognitive Structure," Int. J. Psychol., vol. 1, no. 1, pp. 96-105, 2010, https://doi.org/10.4236/psych.2010.12013.

[30] K. L. Gadzichowski, K.M., Peterson, M. S., Pasnak, R., Bock, A. M., Fetterer-Robinson, S. O. J. M., \& Schme-rold, "A Place for Patterning in Cognitive Development.," Psychology, vol. 9, no. 9, pp. 2073-2082, 2018, doi: https://doi.org/10.4236/psych.2018.9 $\underline{8118}$.

[31] J. Carifio, "The Program Assessment and Improvement Cycle Today: A New and Simple Taxonomy of General Types and Levels of Program Evaluation," Creat. Educ., vol. 3, pp. 951-958, 2012, [Online]. Available: http://www.scirp.org/journal/ce. https://doi.org/10.42 36/ce.2012.326145

[32] et. al Brinker, "Rumination, Mood and Cognitive Performance.," Psychology, vol. 4, no. 3A, pp. 224-231, 2013, https://doi.org/10.4236/psych.2013.43a034.

[33] Z. Chentouf, "Cognitive Software Engineering: A Research Framework and Roadmap," J. Softw. Eng. Appl., vol. 7, pp. 530-539, 2014, https://doi.org/10.4236/jsea.2014.76049

\section{Authors}

Toto Ruhimat is a doctor with the Department of Curriculum and Educational Technology, Universitas Pendidikan Indonesia. His research interests are in Learning Technology, Curriculum, and Mobile Learning. Email: toto.ruhimat@upi.edu

Tata Risdian Rosdiana is a Magister with the department of Educational Technology, Institut Pendidikan Indonesia. His research interests are in Mobile Automatics Electronics System, Mobile Learning, Digital Learning, HumanComputer Interaction. Email: tatarisdianrosdianast@yahoo.com.

Article submitted 2020-04-15. Resubmitted 2020-08-29. Final acceptance 2020-08-30. Final version published as submitted by the authors. 